\title{
WESTMINSTER AS USUAL? \\ THREE INTERPRETATIONS FOR THE UK DEMOCRACY
}

\author{
Marco Giuliani
}

Submitted version.

The published version in Early view is:

Giuliani M (2021). Westminster as Usual? Three Interpretations for the UK Democracy. Government and Opposition: An International Journal of Comparative Politics 1-17. https://doi.org/10.1017/gov.2021.20

\begin{abstract}
The Brexit process has shattered the foundations of British politics, with prime ministerial resignations, government defeats, continuous rebellions and floor crossings. This phenomenon seems at odds with the usual decisiveness of Westminster systems. However, the aforementioned departures from the British tradition could be interpreted as compatible with the typical distance of any empirical reality from theoretical models, as exceptions to the rule due to the specificity of the European issue, or as the surfacing of some deeper social, economic and cultural tensions. Data alone are insufficient to confirm any of the alternative interpretations, although they seem to confirm the existence of longterm dynamics more than some short-term exceptionalism. Within this scenario, the article suggests that a series of institutional innovations introduced since the late 1990s have facilitated the political consolidation of those tensions, contributed to the partisan dealignment, and made room for a potential departure from a Westminster model of democracy.
\end{abstract}

\section{Keywords}

Brexit; Cabinet; Westminster; Model of democracy

Marco Giuliani

Department of Social and Political Science, Università degli studi di Milano, Via Conservatorio 7, 20122 Milano (Italy)

marco.giuliani@unimi.it 


\section{Introduction}

Arend Lijphart took the label for his majoritarian model of democracy from the British Houses of Parliament, and yet he recognized that the United Kingdom is not the purest type of Westminster system (Lijphart 2012). At the core of this vision of democracy (Powell 2000) lies what Walter Bagehot called, more than a century earlier, the 'efficient secret' of the English Constitution, which 'may be described as the close union, the nearly complete fusion of the executive and legislative powers' (Bagehot 1867: 11). This type of institutional architecture, coupled with the typical features of party governments, usually assures swift decisions and a decisive political system (Strøm 2006).

Yet the parliamentary Brexit process revealed a completely different representation of British politics. Two unexpected early general elections were held, but only after having been agreed on the basis of some bipartisan consensus: in 2017 as the direct consequence of the Fixed-Term Parliaments Act, and in 2019 due to the opposition's partial support for and tactical abstention from Johnson's Early Parliamentary General Election Act. Two prime ministers resigned for failing to deliver what they had promised. Numerous ministers quit office, and many MPs rebelled, if not crossed the floor, protesting against the cabinet policies. Successive Conservative minority governments suffered from several parliamentary defeats, in spite of the confidence-and-supply support of the Democratic Unionist Party. A number of senior MPs and former cabinet members had the whip removed, and the executive lost control of the parliamentary agenda on several occasions.

There could be three different interpretations of these events. The first one argues that they are within the likely margin of variation of any empirical case compared to a theoretical model such as that of a Westminster democracy. Indeed, Lijphart himself uses the image of a 'Kuhnian paradigm' when talking about democracies governed by majority rule, where 'discrepancies between facts and theories are not sufficient to lead to its abandonment' (2008: 120). The second interpretation reads those anomalies as the by-products of the uniqueness of the Brexit process or, more extensively, of the specificity of the European issue. As such, they represent the typical exception that proves the rule. The solution to the Brexit conundrum, together with the restoration of a clear parliamentary majority under the second Johnson cabinet, have restored the usual Westminster dynamics of British politics, which were only suspended and not really altered. The last interpretation argues that Brexit has been a critical juncture that has brought to the surface more long-lasting transformations of the British political system. As such, in spite of the apparently extraordinary dynamics recently experienced, what happened was just the tip of a deeper iceberg, whose manifestation does not need to be always as radical as during the years 2018 and 2019, but at the same time will have enduring consequences for the nature itself of the Westminster model of democracy in the UK. Delivering 
Brexit may momentarily curb those dynamics, but they are bound to re-emerge in new ways on some other occasions.

In the absence of any abrupt reform, as in the case of New Zealand in 1996, where a new electoral law had deep consequences for the democratic fabric of the political system, it is not easy to investigate the stability or the transformation of a model of democracy. As such, models should be resilient to changes, but slow-moving transformations could still affect their nature in the long term. For this reason, in the short and medium term, data can only support the plausibility of different interpretations, but not definitely confirm or reject hypotheses regarding the adherence of a political system to a specific archetype.

After identifying some significant behavioural departures from the usual operation of a Westminster democracy, we will connect them to a series of institutional variations that date back to the late 1990s, bolstering a slow but continuous change of British politics made more evident by the peculiarities of the Brexit process.

\section{An empirical overview}

The first breach of a core principle of a Westminster style democracy was the 2010 CameronClegg coalition government, which not by chance was announced by its prime minister during the first press conference as:

a new politics, where the national interest is more important than the party interest, where cooperation wins out over confrontation, where compromise, where give and take, where reasonable, civilised, grown-up behaviour is not a sign of weakness, but a sign of strength.

After 2015, and in spite of all forecasts of a hung parliament, the situation apparently returned to normal, but it deteriorated again in 2017 after the snap election called by Theresa May. For the first months, a confidence and supply agreement with the DUP seemed to resolve several issues, but it proved to be part of the problem when the Irish backstop became the most vulnerable passage of the Brexit agreement. In her resignation statement in front of 10 Downing Street, May advised her successor that:

to succeed, he or she will have to find consensus in parliament where I have not. Such a consensus can only be reached if those on all sides of the debate are willing to compromise. [...] At another time of political controversy, a few years before his death, [Sir Nicholas Winton] took me to one side at a local event and gave me a 
piece of advice. He said: 'Never forget that compromise is not a dirty word. Life depends on compromise.' He was right.

The words in italics signal the similarity of content between the two speeches, as well as the distance from the traditional adversarial style of British politics. May's successor, Boris Johnson, certainly did not take that advice, until he also lost his working majority, after a series of floorcrossings and whip removals (see infra). Everyone knows how the dispute eventually ended, with the prime minister being able to cut the gordian knot, although not after being prevented from doing so several times by a parliament whose powers had been bolstered by the Fixed-term Parliaments Act 2011. ${ }^{1}$

The coalition government and the external support could be anomalies in a linear story of one of the prototypes of majoritarian democracy, and the words of the former prime ministers could be just rhetorical exercises by political leaders trying to cope with the exceptionality of the period. It is difficult to judge from those few empirical items, in spite of their being close to the core of the polar model itself. To complement those observations, we propose to enlarge the focus to comprise four relevant behavioural dimensions relating respectively to: 1) party rebellions; 2) government parliamentary defeats; 3) ministerial resignations; 4) MPs crossing the floor. More in detail, in Table 1 we monitor the evolution of these dimensions for each legislature since 1979, in order to have forty years of observations approximately centred around 1997 as a potential institutional turning point. ${ }^{2}$ The closer these indices are to zero, the more the empirical reality approximates the polar type of Westminster model.

\footnotetext{
${ }^{1}$ This act by itself is another institutional element that contradicts the concentration of power typical of a Westminster democracy, preventing the prime minister from dissolving the parliament at his/her own will (Norton 2016; Schleiter and Evans 2021). The Conservative party promised in its 2019 electoral manifesto to 'get rid of the Fixed Term Parliaments Act, (since) it has led to paralysis at a time the country needed decisive action'. Decisiveness is in fact the essence of a Westminster democracy, and the draft prepared by Johnson's cabinet in December 2020, besides reviving the prime minister's prerogative powers relating to the dissolution of Parliament, also protects them against the judicial review of the Supreme Court, as happened with the 2019 parliament's prorogation.

${ }^{2}$ Data on rebellions refer exclusively to government parties, and have been computed on the basis of data gathered by 'The public whip' project and following its methodology (https://www.publicwhip.org.uk/), complementing those reported by Cowley and Norton (1999) for the years before 1997. Government defeats have been computed from the same source, crosschecked for the first legislatures with data included in the project http://www.election.demon.co.uk/ and in Wikipedia, as well as from the Parliament itself https://www.parliament.uk/about/faqs/house-of-lords-faqs/lordsgovtdefeats/. Resignations have been counted from the 'Whitehall report' of the Institute for Government, and include only those due to political disagreement (https://www.instituteforgovernment.org.uk/publications/whitehall-monitor2020). Floor crossings have been computed from the Research Briefing n. 2357 of the Library of the House of Commons. The index refers only to majority MPs, and excludes multiple crossings during the same legislature or cases in which the whip has been restored after its suspension.
} 
Table 1 Behavioral indices of a Westminster democracy

\begin{tabular}{|c|c|c|c|c|c|c|c|}
\hline Legislature & Cabinets & $\begin{array}{c}\text { Duration } \\
\text { (days) }\end{array}$ & $\begin{array}{l}\text { Divisions } \\
\text { with rebels } \\
\text { (\%) }\end{array}$ & $\begin{array}{l}\text { Government defeats } \\
\text { House of Commons } \\
\text { (per } 1000 \text { days) }\end{array}$ & $\begin{array}{l}\text { Government defeats } \\
\text { House of Lords } \\
\text { (per } 1000 \text { days) }\end{array}$ & $\begin{array}{l}\text { Government } \\
\text { resignations } \\
\text { (per } 1000 \text { days) }\end{array}$ & $\begin{array}{l}\text { Floor crossings } \\
\text { (per } 1000 \text { days) }\end{array}$ \\
\hline 1979-1983 & Thatcher 1 & 1497 & 12 & 0.7 & 30.1 & 0.7 & 0.7 \\
\hline 1983-1987 & Thatcher 2 & 1463 & 16 & 1.4 & 42.4 & 1.4 & 0.0 \\
\hline 1987-1992 & Thatcher 3 - Major 1 & 1764 & 12 & 0.6 & 23.8 & 1.1 & 0.6 \\
\hline 1992-1997 & Major 2 & 1849 & 13 & 3.2 & 33.5 & 1.6 & 2.2 \\
\hline 1997-2001 & Blair 1 & 1497 & 15 & 6.0 & 72.1 & 1.3 & 1.3 \\
\hline 2001-2005 & Blair 2 & 1429 & 30 & 7.7 & 171.4 & 2.8 & 2.1 \\
\hline $2005-2010$ & Blair 3 - Brown & 1831 & 37 & 8.7 & 95.6 & 3.8 & 4.9 \\
\hline 2010-2015 & Cameron 1 & 1823 & 47 & 34.6 & 54.9 & 1.1 & 2.7 \\
\hline 2015-2017 & Cameron 2 - May 1 & 765 & 25 & 11.8 & 124.2 & 1.3 & 0.0 \\
\hline 2017-2019 & May 2 - Johnson 1 & 915 & 34 & 55.7 & 75.4 & 29.5 & 19.7 \\
\hline
\end{tabular}

Source: See endnote 2 
We begin with rebellions, probably the most fine-grained measure of the lack of grip of the executive on the legislative branch. The Brexit process has seen a series of rebellions by majority MPs, including various members of the executive, and it has produced the largest government defeat in modern British political history. Hence it can be easily portrayed as a perfect storm for a parliamentary democracy (Russell 2021). Yet the record amount of backbench dissent in the House of Commons was not during the last legislature, and did not concern the European Union, but rather a government motion over Iraq during the second cabinet led by Tony Blair.

If we observe the fourth column in Table 1, we note that the late 1990s represent a sort of watershed between two decades of relatively few rebellions, and another two decades of much more frequent revolts. ${ }^{3}$ In the latter legislatures, the share of divisions with at least one rebel is twice or even three times higher than in the preceding period. Furthermore, while the coalition government was understandably more exposed to rebellions than single-party ones, the relative length of the honeymoon period in shorter legislatures, and the higher perceived costs of rebellion in the case of minority governments did not reduce the amount of backbench dissent as the theory would expect. ${ }^{4}$ Controlling for the above factors, we recognize a regular increase of rebellions for the whole 19972019 period, with a progression that is confirmed also if we include in the analysis the revolts of opposition MPs, so that the increase cannot be attributed to any specific party characteristics.

In Table 2 we investigate in more detail the hypothesis of a gradual but systematic slackening of the grip of the different cabinets on their backbenchers over time, focussing on the years after 1997. The various regression models include in the right-hand side of the equation a time variable, the year of the division, together with a series of dummy control variables. The first one accounts for free votes, in order not to conflate the real degree of dissent by including divisions in which there was no form of explicit or implicit whip. The second one reflects our observation regarding the coalition government of the 2010-15 legislature, naturally exposed to greater defections. Finally, we include a dummy variable for divisions that deal with EU issues, clearly the topic that elicited many dissenting voices in the Parliament over the years. ${ }^{5}$

\footnotetext{
${ }^{3}$ Extending the analysis to the whole post-WW2 period (Cowley and Norton 1999), we can estimate that the average share of contested divisions within the majority in the legislatures before the 1970s was slightly less than 6\%; it grew to around 15\% in those between 1970 and 1997, and topped almost 32\% afterwards.

${ }^{4}$ Focusing on the last legislature, resignations from Theresa May's second cabinet were higher than from Boris Johnson's second cabinet, as was higher the rate of divisions with government rebels (also due to the fact that the 21 MPs expelled from the Conservative parliamentary party in early September 2019 can no longer be counted as such). However, the frequency of floor-crossings and government defeats was higher under Johnson than under May.

${ }^{5}$ We looked conservatively for the presence of the words 'EU' or 'Europe*' in the title of the division.
} 
Table 2 Regressing dissent on time (OLS coefficients and logit odds ratio with standard errors)

\begin{tabular}{|c|c|c|c|}
\hline & $\begin{array}{c}(1) \\
\text { Number Rebels } \\
\text { OLS } \\
\end{array}$ & $\begin{array}{c}\text { (2) } \\
\text { Dummy Rebels } \\
\text { Logit OR } \\
\end{array}$ & $\begin{array}{c}\text { (3) } \\
\text { Dummy defeat } \\
\text { Logit OR }\end{array}$ \\
\hline Free vote & $\begin{array}{c}38.20 * * * \\
(1.13)\end{array}$ & $\begin{array}{c}47.56 * * * \\
(16.49)\end{array}$ & $\begin{array}{c}11.13^{* * *} \\
(3.33)\end{array}$ \\
\hline EU & $\begin{array}{c}2.72 * * * \\
(0.63)\end{array}$ & $\begin{array}{c}1.67^{* * * *} \\
(0.16)\end{array}$ & $\begin{array}{c}2.36^{* * *} \\
(0.49)\end{array}$ \\
\hline Coalition & $\begin{array}{c}1.50 * * * \\
(0.47)\end{array}$ & $\begin{array}{c}2.12^{* * *} \\
(0.16)\end{array}$ & $\begin{array}{c}1.90 * * * \\
(0.32)\end{array}$ \\
\hline Year & $\begin{array}{c}0.07 * * \\
(0.03)\end{array}$ & $\begin{array}{c}1.04 * * * \\
(0.01)\end{array}$ & $\begin{array}{c}1.14^{* * *} \\
(0.02)\end{array}$ \\
\hline Constant & $\begin{array}{c}-129.25^{* *} \\
(62.97)\end{array}$ & $\begin{array}{c}0.00 * * * \\
(0.00)\end{array}$ & $\begin{array}{c}0.00 * * * \\
(0.00)\end{array}$ \\
\hline $\mathrm{N}$ & 5976 & 5976 & 5976 \\
\hline
\end{tabular}

The first model aims at explaining the number of government rebels. The impact of time is positive and systematic, confirming our intuition of a positive trend of rebellions. At first sight, the magnitude of that effect seems negligible, but it should be borne in mind that we are talking of averages taken on literally hundreds of divisions in which the Westminster baseline should be to have no rebels at all. All our control variables are highly significant: free votes do not respect the standard government/opposition divide; divisions under the coalition government have on average one and a half more rebels; and the EU is a major factor triggering dissent within the governing parties. ${ }^{6}$

The second model, accounting for the presence of at least one dissenting MP within the majority, confirms and contributes to the robustness of the previous findings. Each year there is a $4 \%$ greater probability of having rebellious behaviour in the House of Commons within the governing parties. All other things being equal, the probability more than doubled during the 2010-15 legislature, and if the division tackled EU issues there was an additional $2 / 3$ probability of having at least one MP rebelling.

To rebel in a division against the party directives is a personal choice, whose political consequences vary according to whether or not it contributes to a parliamentary defeat. Thus, a more severe symptom of divergence from the traditional Westminster democracy is the frequency of government defeats in the House of Commons, whose values are reported in column five of Table 1

\footnotetext{
${ }^{6}$ To check for the disproportional impact of specific events, we also replicated our models cancelling, one after the other, all the divisions of a specific year, confirming the robustness of our findings. We obtained similar results by substituting the exact date of the division for the year variable.
} 
disaggregated for the different legislatures. The index probably overestimates the importance of those losses for the period of the coalition government, since we counted as a government defeat every time (the majority of MPs of) either the Conservatives or the Liberal-Democrats happened to be on the losing side of the division. If we considered as defeat in that period only when both parties happened to be in a minority, largely underestimating its political meaning, the index would decrease to a value close to that of the second Major cabinet, still being much higher than in the first three legislatures.

In both cases, we can still recognize the steady increase of the frequency of government setbacks since the early 1990s, and especially after 1997. Compared to less than 1 defeat every 1000 thousand days in the first three legislatures, the weak second Major cabinet had three times more setbacks. Yet after the Labour landslide victory of 1997 the frequency of defeats doubled again, and continued to progress until 2019 irrespective of the government formula. The third model in Table 2 confirms this impression: after 1997, each year saw a 14\% increase in the probability of witnessing a government defeat, which was further boosted in the case of divisions dealing with EU issues, when the probability of losing the parliamentary vote was more than twice than usual. ${ }^{7}$

Defeats in the House of Lords, in the sixth column of Table 1, do not have the same political significance. Yet they are worth exploring especially considering that no party controlled the majority of the members of that House. Apart from the second Blair cabinet, which is clearly an outlier, we observe a trend that parallels the one in the House of Commons, with a frequency of defeats in the last legislatures that is two or three times higher than that of the first period taken into consideration.

Another measure reported in Table 1 is the frequency of cabinet resignations due to policy disagreement, a further indicator of the fact that the hierarchical structure of the British cabinet is no longer able to produce collegial decisions and control its internal conflicts. Here the values seem more stable, with the important exception of the 2017-19 legislature, which saw an exceptionally high number of resignations, mostly due to dissent with the government's approach to the Brexit issue on both sides of the dispute. Yet, once again, if we discount for the possible 'honeymoon' of the two executives in the shorter 2015-17 legislature, and for the delicate equilibrium of the coalition government, we realize that since the 1990s there has been a slow but consistent increase in the frequency of government defections.

\footnotetext{
${ }^{7}$ We are not claiming that the trend needs to progress always at the same pace, or that there cannot be a decrease in that frequency, but only that the new 'baseline' is higher than in the past. Despite the honeymoon period and the Covid emergency, the second Johnson cabinet has already been defeated twice in approximately six months, a value which is similar to that of the 2015-2017 legislature.
} 
A similar trend is apparent also for the last index reported in Table 1, probably the strongest manifestation of misalignment between an MP and his/her own party, i.e. the autonomous decision to change parliamentary group and/or the party's decision to definitively remove the whip from one of its members. Abandoning the governing party for political reasons was almost an unknown phenomenon under Thatcher's cabinets. It became relatively more common in the 1990s, and the frequency further increased between 2005 and 2015. After that date there was the twofold anomaly of the short 2015-2017 legislatures, with no floor-crossings, and of the 2017-2019 legislature, with many Tories abandoning or being expelled from their parliamentary party and increasing the number of independent MPs, or joining the Liberal-Democrats or, momentarily, the new Change UK parliamentary group. If we clustered the four legislatures before 1997, on the one hand, and the six legislatures after that date on the other, the average frequency of floor-crossings in the first period would be just below 1 in every thousand days during the first period, and more than four times higher in the second one.

Floor-crossings are always the result of the deterioration of relations between an MP and his/her political leader, often because of policy or political divergencies. Usually, the strict selection of the political élites under a party government prevents the emergence of harsh frictions. Their development is per se a symptom that the parties are failing to funnel the divergent opinions, and that a different, more cooperative approach may be required. A clear example is provided by the null result of the series of indicative votes taken in the House of Commons after Theresa May failed to have her EU agreement approved in parliament. On the one hand, the fact that a cabinet was unable to gain approval for the most important act of its mandate was a sign of the limitations of a majoritarian approach to the issue. However, on the other hand, that same adversarial style prevented the quest for alternative solutions.

In this regard, it is worth recalling the words used by Nick Boles, a Conservative MP, when he announced to the House that he was resigning from his parliamentary group at the end of the inconclusive second round of indicative votes:

I have given everything to an attempt to find a compromise that can take this country out of the European Union while maintaining our economic strength and our political cohesion. I accept that I have failed. I have failed chiefly because my party refuses to compromise. I regret, therefore, to announce that I can no longer sit for this party. (HC Deb 1 April 2019, vol. 657, col. 880)

To summarize, there are a series of signals that the British Westminster democracy, and especially its central institution, the cabinet, have not worked as they used to do. Coalition and 
minority cabinets are the most evident symptoms of that syndrome, but we have proposed also a series of subtler indices to evidence an ongoing dynamic that we propose to date back to the second half of the 1990s. In this respect, the last 2017-19 legislature could be an odd outlier, more or less as the mid1970s stand apart from the rest of the post WW2 British history. Or it could have been the outcome of the underlying frictions that had accumulated in the past 20 years, which suddenly exploded in the Brexit 'perfect storm', as in the earthquake metaphor used by policy scholars of the punctuated equilibrium school (Baumgartner et al. 2014). Data are in theory compatible with different interpretations, so that understanding what the exception is, and what the rule is, requires further widening the focus of the analysis.

\section{The Westminster benchmark}

From a constitutionalist point of view, what represents the essence of Westminster systems is debatable and contested. 'There is no single essentialist definition on which in the present context we can all agree. It is probably futile to try' (Rhodes et al. 2009: 9). In terms of conceptualization, this means that scholars not agreeing on a set of properties defining the connotation of the concept along the ladder of abstraction resort to non-classical understandings, such as radial or family-resemblance categories (Collier and Mahon 1993). While this strategy can accommodate the parallel investigation of different country experiences, it can hardly help in the longitudinal analysis of a single political system. Conversely, Russell and Serban (2020), who prefer to follow the classical inverse relationship between intension and extension of social science concepts, ends up with a radical proposal. Worried by the conceptual stretching in the use of the term 'Westminster model', they go so far as to suggest its retirement.

In contrast to the two perspectives outlined above, we prefer to consider a pure Westminster democracy as one of the two opposites of a polar types approach: countries are closer to, or farther away from, two empirical (not ideal) extreme types according to a set of independent variables, so that it is possible to quantify them into indices before clustering and averaging them into specific dimensions and scales (Lijphart 2012). Thus, in opposition to consensual systems, Westminster democracies can be seen as characterized by an adversarial two-party system, competing on a singledimensional space, tightly governed from its centre by a collegial executive monopolistically controlling the legislative agenda by means of a hierarchic cabinet firmly led by a prime minister, and relying on disciplined parliamentary parties.

Philip Norton (2019) dates back to the 1970s a major departure from this tradition which involved behavioural, structural and constitutional changes that impacted on the executive/legislative 
relationship and on the link between the Parliament and the people. Yet there may be three different interpretations of those transformations: a) they are within the range of the possible variability of a Westminster democracy; b) they are the outcome of the exceptionality of the European, and especially Brexit, issue; c) they are symptoms of some deeper change of the British model of democracy. The differences amongst those alternative understandings can be both theoretical and empirical, and we cannot clarify all of their different nuances in this article. We will only consider a few arguments or reference points for the first two interpretations, before spending some more time on the third one.

As said above, and apart from those who see no utility in the term as such, there is an ongoing debate on the exact meaning, and thus on the empirical extension, of the concept of Westminster democracy. At one extreme of that debate, Rhodes et al. (2009) argue in favour of a flexible bottomup definition of the concept that accommodates a variable set of ideas, beliefs and practices which the political actors operating in those contexts recognize. A Westminster democracy is what those actors make of it, since 'it may mean different things to actors in different countries' (229). However, if the concept eventually coincides with a 'loose family of governments' (229), it becomes impossible to evaluate any empirical trajectory of the countries identifying themselves in that model. If a Westminster country changes, the model adapts itself to those changes.

This perspective is certainly a good antidote against the myth of a golden age of Westminster democracies, but at the same time it underestimates the possibility that countries can depart from their usual path, since any diversion should be considered a reinterpretation of that 'living tradition' (45). On adopting this perspective, it is natural not to consider the changes described in the preceding section as resulting from changes in the model of democracy. In its history, the UK has experienced other times in which the familiar majoritarian dynamics have been momentarily suspended, but the model itself has proved to be much more resilient. At the end of the day, can the democracy that lives in Westminster not be a Westminster democracy?

The second interpretation does not underestimate the institutional and behavioural changes reported in the preceding section, but confines them to the exceptionality of the Brexit process, or, at worst, of the European issue. The sensitivity of the British political system to the EU dates back to, the accession of the UK to the then European Communities in 1973. The first national referendum confirming the membership in 1975, the internal dissent on the European Exchange Mechanism that contributed to the end of Thatcher's third ministry in 1990, the rebellion on ratification of the Maastricht Treaty under John Major's cabinet in 1992, the success of Eurosceptic parties since 2004, are just a few reminders of how Europe has never really fitted with the political history of its 'awkward partner' (George 1998). The Brexit referendum, the resignations of David Cameron and Theresa May, the two early elections, the exceptional rate of parliamentary revolts, government 
defeats and floor-crossings of the last legislatures have the same denominator: the European Union. According to this reading, which often attributes the misfit to identity issues (Carl et al. 2018), by ending the EU affair (Prosser 2021) the approval of the exit agreement and the 2019 general election have also ended the period of anomaly and realigned British politics (Cutts et al. 2020).

\section{A third perspective}

While the first interpretation depends on its theoretical perspective, the second one is mostly an empirical issue, whose plausibility has been strongly reinforced by Johnson's victory. However, there is a third possibility. It suggests that the Brexit conundrum is not at the origin of the UK transformations; rather, it is one of its effects. There was more than just the pace of European integration behind the Brexit vote; likewise, there is more than just the EU behind those changes. The focus of the analysis needs to be both enlarged, to include institutional and societal transformation, and deepened, to admit long-lasting effects than cannot appear and disappear with some bold decision like delivering Brexit. In order to advocate in favour of this third perspective, we will first reconstruct the scholarly debate centred on the most important dynamics in British politics of the last few years, and then link it to a number of institutional transformations that could consolidate those changes in the longer term, regardless of the apparent setbacks of late 2019.

Strohmeier (2018), explicitly adopts Lijphart's perspective in sketching a 'consensualisation' of the British Westminster model. However, on updating his traditional variables, he also argues that that process could have been stopped already with the 2015 general election. Baldini et al. (2018, 2021) glimpse a recent reinforcement of the majoritarian character of the British political system following the 2016 Brexit referendum, though they do not exclude other adjustments in the future. ${ }^{8}$ Other scholars instead believe that the executive remains exposed to countervailing domestic powers different from the EU, such as the devolved governments, the courts, or parliament itself (Sumption 2020; Young 2017).

Taking a bottom-up approach, Carreras et al. (2019) identify the main political changes not at the constitutional level, but at the societal one, and especially in the failure to represent the differentiated effects produced by globalization in the country. The transformations triggered by Brexit are the manifestation of a multifaceted crisis, 'a symptom of longer-term social changes that

\footnotetext{
${ }^{8}$ They admit that the 'move back towards the Westminster model is clearly constrained': 'high volatility leaves the twoparty system in a vulnerable position'; 'Parliament is now structurally better equipped to challenge the government'; and 'so far, Brexit has not cancelled the important constitutional reforms adopted since 1997', including devolution and the role of the Supreme Court.
} 
have quietly been reshaping public opinion, political behaviour, and party competition in Britain' (Ford and Goodwin 2017: 17). Evans and Menon (2017) take the same longitudinal approach, and identify substantially similar drivers of change - consisting of economic crises, identity issues and migration problems, with Europe acting as the catalyst of those tensions - but they also focus on the supply side, i.e. on the inability of political élites to tackle the fears produced by those societal transformations. The ideological convergence of the major parties, the centripetal competition to represent the middle class, the technocratic turn in many policy decisions, are all factors that have produced political dissatisfaction, disillusionment and depoliticization in growing portions of the electorate, particularly in 'the working class, the poor and the less educated, on both left and right' (34). This partisan dealignment has favoured unprecedented level of electoral volatility and, eventually, reduced the predictability of electoral results. The public perception of the major parties has been influenced by a series of electoral shocks - ranging from migration to economic recession, from the coalition government to the two referenda - that are thought to have long-lasting consequences because younger cohorts with weak partisan attachment are going to substitute older identified groups (Fieldhouse et al. 2019). As Sobolewska and Ford (2020) put it, 'the changes which drove Brexit will continue to generate volatility and political change for many years to come' (2).

This evolution has eroded the social bases of the Westminster model, weakening the traditional unidimensional left-right competition, the one that ensures the coherence of an adversarial style of politics, and introducing new social divides. ${ }^{9}$ Majoritarian institutional set-ups are typically extremely resilient to these bottom-up pressures, and in the United Kingdom they have usually been efficient in protecting the so-called British Political Tradition. Hall et al. (2018) argue that the recent challenges to British democracy have led more 'to adaptation and accommodation, rather than wholesale change' (378). However, they do not rule out that, in the absence of any 'simple solution, (...) challenges to established political practice in the UK are only likely to intensify further, in both resonance and scope'. Lacking an institutional anchorage - that is, without what has been called in political sociology a 'favourable structure of political opportunities' (Tarrow 1988) - social changes cannot directly transform a model of democracy. These opportunities depend, among other things, on the degree of openness of the political system.

In this regard, a Westminster democracy usually filters the representation of societal differences by means of a highly disproportional electoral system. The typical underrepresentation of third parties

\footnotetext{
${ }^{9}$ Jennings and Lodge (2018) argue that, whereas these social challenges may be not unique to the United Kingdom, the way in which they interacted with the pre-existing institutions posed specific problems to British politics.
} 
is an effective barrier to the entry of less traditional, locally-based, or single-issue preferences, as well as demands that are not aligned along the usual left-right dimension. The major parties have no interest in making the system more inclusive; rather, they accommodate under their umbrellas potentially diverse interests. In turn, in this closed system, citizens have no incentive to vote sincerely for some minor party, and act strategically by voting for a less-preferred candidate who has greater chances of accessing the institutions. According to the well-known Durverger's law, the combined mechanical and psychological effects of the plurality electoral formula on both citizens and parties favour the formation and maintenance of the two-party system at the basis of Westminster democracies.

Since the late 1990s there have been two main factors that have indirectly changed this state of affairs: first, the establishment of devolved parliaments in Scotland and Wales, together with the Northern Ireland Assembly; second, the first election for the European Parliament in the United Kingdom using a PR formula. Both types of election, local and supranational, adopt more permissive electoral systems, thus favouring the emergence and success of parties usually marginalised in general elections. The effective threshold in these systems, an estimate of the share of votes required to have a reasonable expectation to gain a seat at the district level, is between 2 to 4 times smaller than under the first-past-the-post system used in general elections. The level of disproportionality has thus been much lower in the PR election for the European Parliament, in the Additional Member System for the Scottish and Welsh parliament, and in the Single Transferable Vote used in the Northern Ireland Assembly, compared to the plurality used for the House of Commons. Since the late 1990s, the average Gallagher index has been respectively 7.5 for the European Parliament, 7 in Scotland, 10.5 in Wales, and 3.8 in Northern Ireland, compared to 14.6 for the Parliament in London.

The existence of a series of significant second-order elections favouring a clearly different pattern of representation has an important consequence for the first-order one. Parties and preferences usually underrepresented in Westminster, squeezed by the disproportionality of its two-party competition, have for the first time had their own institutional venues, and have been able to consolidate their territorial bases without being viewed as symbolic waste votes. Nationalist, green, and single-issue parties have boosted their credibility through the success gained in these alternative venues. This has not translated automatically into their greater competitiveness on the national political stage, with the notable exception of the Scottish National Party, but into the necessity for all major candidates to pay attention to those diverse instances. Over time, this situation has produced, firstly, a more open race at the district level, secondly, a larger volatility of the electorate, and eventually greater uncertainty about the aggregate result. 
If we use the series of the electoral results from 1945 to 2017, and regress the sum of the share of the votes for the first two parties in each district on the year of the election, we obtain a significant negative coefficient for the time variable, i.e. a systematic decrease in support for the two frontrunners. The same happens if we consider the electoral margin between the first and third party, or the probability of winning a seat with the absolute majority of votes, both of which are signs of the increasing competitiveness of the election at the district level, and thus of the overall uncertainty of the result at the aggregate one. These average trends suggest that the two-party dynamics of the 2017 and 2019 election could be a parenthesis, more than a return to the standard tradition. ${ }^{10}$

These changes also impacted on other traditional electoral and party-fragmentation indices. Compared to the average value of Thatcher's and Major's legislatures, the effective number of electoral parties increased after 1997 by approximately 10\%, while the same index for parliamentary parties increased by $15 \%$. Average aggregated volatility increased by more than $40 \%$ between the two periods. Also what Blau (2008) calls the effective number of legislative and governmental parties saw an upturn, mostly due to the minority (and eventually insufficiently supported) cabinets after 2017, and the coalition government during the 2010-15 legislature.

In democracies, elections represent the major entry points for institutional changes, mostly because their outcomes generate a series of potentially profound changes. As Sartori (1994: 3) put it in his book on constitutional set-ups, 'in the beginning is how a people is made to vote'. The greater competitivity and volatility that spilled over from second- to first-order elections produced greater opportunities for realignments between public opinion and political élites, and eventually further divisions amongst and within them (Cutts et al. 2020; Gamble 2019). These are two factors further considered by Tarrow (2011) as opportunity structures for introducing societal changes in the institutional fabric of a political system.

The realignment is evidenced by the major restructuring in the geography of the vote in the last elections, due to the fact that traditional social classes divides were less able to predict voting behaviours. The ruptures between and within the political élites were particularly evident in the last two years before the 2019 general election, and again reflected significant socio-economic divides.

\footnotetext{
${ }^{10}$ Heath and Goodwin (2017: 357) discuss this possibility, concluding that 'the move towards two-party politics may also turn out to be a blip rather than a permanent realignment, and there is still the potential for minor parties to reassert themselves' (357). Interestingly, they add: 'One thing, however, appears fairly certain. While the 2017 general election result defied predictions and also easy explanations, the next election — whenever it is called — will also have the capacity to surprise'. John Curtice (2020: 45), while acknowledging the fact that the 2019 election delivered a clear majority, raises a few doubts that this result actually signals a stable return to a Westminster normalcy, remaining 'a high probability that future elections will result in more hung parliaments'.
} 
The Irish backstop, and what it represented, nurtured a geographical divide within the government working majority with the Democratic Unionist Party, whereas the position of the Scottish National Party sometimes prevented the opposition from finding a compromise on some parliamentary solution alternative to Brexit. Rebelling or not for Conservative MPs was not just a personal decision, but systematically reflected the preferences expressed by each MP's constituency during the Brexit referendum, and some deeper socio-economic structure of the electorate (AA 2019). The same applies also to Labour MPs rebelling in support of May's or Johnson's exit agreements.

\section{Back to business as usual?}

Our thesis is that the problems experienced during the Brexit parliamentary process should not be considered short-term anomalies or entirely dependent on the EU divide; rather, they should be framed within a broader and longer-term interpretation. The dealignment between large segments of the electorate and the political élites has social, economic and cultural origins, but it would have been reabsorbed if they had not been anchored in an institutional opportunity structure that started to change already in the late 1990s.

The main objection to this interpretation is that, although there have been some evident oddities, they mostly depended on the imperfect majorities of the past decade, connected to a period of complex choices. Whatever happened in those years, the end of the Brexit process will also restore the traditional Westminster dynamics. Clear signs of this restoration have already come from the 2019 general election, the landslide victory of the Conservative party and the consequent second Johnson ministry leading a single-party cabinet enjoying a wide and more disciplined majority in parliament. In short, there have certainly been exceptions, but, as the saying goes, they only prove the rule.

We are not convinced by this argument for two different sets of reasons. On the one hand, we should believe that those imperfect contentious majorities and hung parliaments were just quirks of fate, and not the outcomes of longer societal processes described by a large number of scholars and concisely summarized in the previous section. We believe that they were the effect of something bigger, and not just some random occurrence. On the other hand, single events never prove or disconfirm a claim regarding the long-term evolution of a democracy. While the last two (if not three) elections seem rather exceptional, at least for having been dominated by the single issue of Brexit, the institutional argument that we have presented identifies the constant underground forces that we believe started to affect the foundations of British politics.

Devolution has fostered the establishment of parallel and diverse political systems that threaten the unitary character of the country, and that require a more cooperative approach in order to avoid 
otherwise potentially disrupting centrifugal tendencies. Referendums, i.e. a direct form of democracy more akin to a consensual rather than majoritarian model, have been used since 1997 not just for deciding on EU membership, but for several UK-wide or subnational constitutionally important issues. The House of Lords has been able to extend its influence as soon as the House of Commons was no longer under the direct control of the executive (Smith 2019). Even the supreme court affirmed its power vis-à-vis the executive prerogatives when different cabinets tried to extend them without having the usual loyal partisan support, as happened first with Theresa May and the necessity of a parliament act for invoking art. 50, and then with the prorogation controversy under the first Johnson cabinet (Eleftheriadis 2017; Sumption 2020).

These are not just behavioural dynamics depending on the contingent government majority. They are also alternative authoritative institutions at odds with the fusion of powers recalled by Bagehot's efficient secret. To use a popular saying, once the genie of consensualism has been freed, it is difficult to put it back into its bottle. Europe has been a traditional confrontational issue in British politics, and yet it should not be mistaken as a peculiar element at odds with its tradition. The EU divide has been the most visible representation of the institutional tensions connected to the process of globalization, and of the imperfect political attempts to exploit its economic opportunities, on the one hand, while taming its consequences on the other. This is the reason why the Leave/Remain vote was not dictated by a debate on the different models of integration, but rather by issues of identity, migration, economic and social protection (Colantone and Stanig 2018; Curtice 2017; Ford and Goodwin 2017; Jennings and Stoker 2017).

As such, while the way in which these tensions and divides have led to the Referendum and to Brexit is specific to the UK, they have simply taken other forms in other contexts, such as the growth of populist and nationalist parties, especially after the Great Recession, and the transformation of the space of political competition (Margalit 2019; Pappas and Kriesi 2015). If this is true, and apart from a predictable honeymoon period, whose duration is entirely determined by unpredictable circumstances, there are no reasons why Brexit should solve those problems or eradicate those deeper issues. In turn, removing the 'European institutional layer' is not guaranteed to restore the cabinet's centrality within a renewed parliamentary sovereignty (Young 2017).

Each model of democracy rests on a combination of institutional and political factors that mutually reinforce each other. We have described how this reciprocal support has not occurred in the past two decades in the British case, and put forward an explanation as to why it could further manifest its limits in the future. We are not advocating a post-Brexit consensual style (Richardson 2018); nor are we suggesting that it could represent a prototype for what has been dubbed a new model of 'cooperative majoritarianism' (Blondel and Battegazzorre 2003). We have simply framed the troubled 
years after the EU referendum in a longer temporal perspective; as the abrupt surfacing of underlying societal and institutional frictions, and not as an exceptional period that has already come to an end. 


\section{References}

Bagehot W (1867) The English Constitution. Oxford: Oxford University Press.

Baldini G et al. (2018) Who is in Control? Brexit and the Westminster Model. The Political Quarterly 89(4), 537-544.

--- (2021) Back to the Westminster model? The Brexit process and the UK political system. International Political Science Review 10.1177/0192512120967375.

Baumgartner FR et al. (2014) Punctuated Equilibrium Theory: Explaining Stability and Change in Public Policymaking, In Sabatier PA and Weible CM (eds.), Theories of the Policy Process. Boulder: Westview Press, pp. 59-103.

Blau A (2008) The Effective Number of Parties At Four Scales. Party Politics 14(2), 167-187.

Blondel J and Battegazzorre F (2003) 'Majoritarian' and 'consensus' parliamentary democracies: a convergence towards 'cooperative majoritarianism'? Quaderni di Scienza Politica 9, 225-251.

Carl N et al. (2018) European but not European enough: An explanation for Brexit. European Union Politics 20(2), 282-304.

Carreras M et al. (2019) Long-Term Economic Distress, Cultural Backlash, and Support for Brexit. Comparative Political Studies 52(9), 1396-1424.

Colantone I and Stanig P (2018) Global Competition and Brexit. American Political Science Review 112(2), 201-218.

Collier D and Mahon JE (1993) Conceptual "Stretching" Revisited: Adapting Categories in Comparative Analysis. The American Political Science Review 87(4), 845-855.

Cowley P and Norton P (1999) Rebels and rebellions: Conservative MPs in the 1992 Parliament. British Journal of Politics and International Relations 1(1), 84-105.

Curtice J (2017) Why Leave Won the UK's EU Referendum. JCMS: Journal of Common Market Studies 55, 1937.

--- (2020) A Return to 'Normality' at Last? How the Electoral System Worked in 2019. Parliamentary Affairs 73(Supplement_1), 29-47.

Cutts D et al. (2020) Brexit, the 2019 General Election and the Realignment of British Politics. The Political Quarterly 91(1), 8-23.

Eleftheriadis P (2017) Constitutional Illegitimacy over Brexit. The Political Quarterly 88(2), 182-188.

Evans G and Menon A (2017) Brexit and British Politics. Cambridge: Polity Press.

Fieldhouse E et al. (2019) Electoral Shocks: The Volatile Voter in a Turbulent World. Oxford: Oxford University Press.

Ford R and Goodwin M (2017) A Nation Divided. Journal of Democracy 28(1), 17-30.

Gamble A (2019) The Realignment of British Politics in the Wake of Brexit. The Political Quarterly 90(2), 177186.

George S (1998) An Awkward Partner: Britain in the European Community. Oxford: Oxford University Press.

Hall M et al. (2018) A changing democracy: contemporary challenges to the British political tradition. Policy Studies 39(4), 365-382.

Heath $\mathrm{O}$ and Goodwin M (2017) The 2017 General Election, Brexit and the Return to Two-Party Politics: An Aggregate-Level Analysis of the Result. The Political Quarterly 88(3), 345-358.

Jennings W and Stoker G (2017) Tilting Towards the Cosmopolitan Axis? Political Change in England and the 2017 General Election. The Political Quarterly 88(3), 359-369.

Jennings $\mathbf{W}$ and Lodge $\mathbf{M}$ (2018) Brexit, the tides and Canute: the fracturing politics of the British state. Journal of European Public Policy 26(5), 772-789.

Lijphart A (2008) Thinking about Democracy. Power Sharing and Majority Rule in Theory and Practice. London: Routledge.

--- (2012) Patterns of Democracy. Government Forms and Performance in Thirty-Six Countries. New Haven: Yale University Press. 
Margalit Y (2019) Economic Insecurity and the Causes of Populism, Reconsidered. Journal of Economic Perspectives 33(4), 152-170.

Norton P (2016) The Fixed-term Parliaments Act and Votes of Confidence. Parliamentary Affairs 69(1), 3-18.

--- (2019) Is the House of Commons Too Powerful? The 2019 Bingham Lecture in Constitutional Studies, University of Oxford. Parliamentary Affairs 72(4), 996-1013.

Pappas TS and Kriesi H (2015) Populism and Crisis: A Fuzzy Relationship, In Kriesi H and Pappas TS (eds.), European Populism in the Shadow of the Great Recession. Colchester: ECPR Press, pp. 303-325.

Powell GB (2000) Elections as instruments of democracy : majoritarian and proportional visions. New Haven, CT: Yale University Press.

Prosser C (2021) The end of the EU affair: the UK general election of 2019. West European Politics 44(2), 450461.

Rhodes RAW et al. (2009) Comparing Westminster. Oxford: Oxford University Press.

Richardson J (2018) British Policy-Making and the Need for a Post-Brexit Policy Style. London: Palgrave.

Russell M (2021) Brexit and Parliament: The Anatomy of a Perfect Storm. Parliamentary Affairs 74(2), 443463.

Russell M and Serban R (2020) The Muddle of the 'Westminster Model': A Concept Stretched Beyond Repair. Government and Opposition 10.1017/gov.2020.12, 1-21.

Sartori G (1994) Comparative Constitutional Engineering. An Inquiry into Structures, Incentives and Outcomes. Basingstoke: MacMillan.

Schleiter P and Evans G (2021) The Changing Confidence Relationship Between the UK Executive and Parliament in Comparative Context. Parliamentary Affairs 74(1), 121-137.

Smith J (2019) Fighting to 'Take Back Control': The House of Lords and Brexit, In Christiansen T and Fromage D (eds.), Brexit and democracy. The Role of Parliaments in the Uk and the European Union. Basinstoke: Palgrave, pp. 81-103.

Sobolewska M and Ford R (2020) Brexitland. Identity, Diversity and the Reshaping of British Politics. Cambridge: Cambridge University Press.

Strohmeier G (2018) Does Westminster (Still) Represent the Westminster Model? An Analysis of the Changing Nature of the Uk's Political System. European View 14(2), 303-315.

Strøm K (2006) Parliamentary Democracy and Delegation, In Strøm K, et al. (eds.), Delegation and Accountability in Parliamentary Democracies. Oxford: Oxford University Press, pp. 55-106.

Sumption J (2020) Brexit and the British Constitution: Reflections on the Last Three years and the Next Fifty. The Political Quarterly 91(1), 107-115.

Tarrow S (1988) National Politics and Collective Action: Recent Theory and Research in Western Europe and the United States. Annual Review of Sociology 14, 421-440.

--- (2011) Power in Movement. Social Movements and Contentious Politics. Cambridge: Cambridge University Process.

Young AL (2017) The Constitutional Implications of Brexit. European public law 23(4), 757-786. 